\title{
基于RIOHTrack足尺加速加载试验的长寿命 饬青路面行为研究进展
}

\author{
张蕾, 周兴业, 王旭东 ${ }^{*}$ \\ 交通运输部公路科学研究院, 北京 100088 \\ *联系人, E-mail: xd.wang@rioh.cn \\ 2020-03-18 收稿, 2020-05-06 修回, 2020-05-07 接受, 2020-05-08 网络版发表 \\ 中央级公益性科研院所基本科研业务费专项(2019-0027)资助
}

\begin{abstract}
摘要 采用足尺加速加载试验模拟和研究路面长期服役性能, 是世界公认的最为高效、对自然和荷载耦合作用仿 真度最高的技术手段, 是路面设计理论发展的重要支撑. 面向新一代长寿命路面技术目标, 充分发挥足尺加速加载 试验的优势, 深入揭示荷载与环境耦合作用下的复杂路面结构行为机理, 是革新路面设计方法的有效途径之一. 第 S54次香山科学会议“中国长寿命路面关键科学问题及技术前沿”的议题之一“路面足尺试验的目标与科学问题”, 即立足国内外足尺加速加载试验研究的主要经验与贡献, 对研究目标和科学问题进行了讨论, 进一步明确了该领 域的发展方向和研究重点. 本文通过对我国首条足尺加速加载路面试验环道RIOHTrack(Research Institute of Highway MOT Track)设计理念及研究进展的介绍, 论述了长期持续观测积累的科学数据对于认识、发现路用性能演化 规律的重要性, 以及由现象学层面特征和差异出发, 遵循现象发现-理论解析-实践验证的路面工程研究方法论, 在 非线性力学分析体系、多元仿真模型构建等研究方面取得的主要进展.
\end{abstract}

关键词路面行为, 足尺, 加速加载试验, 交通运输部公路科学研究院环道(RIOHTrack), 长寿命励青路面

足尺加速加载试验是路面学科的一种大型科学实 验, 是在与实际相同或类似的路面结构体系上, 通过加 速加载的方式, 施加不小于标准轴重的实际轮载, 得以 在较短的试验周期下，模拟路面结构全寿命周期的响 应特性和性能演变规律 ${ }^{[1]}$. 该试验对完善路面设计体 系、健全设计模型与指标、提高设计可靠性起到重要 作用. 美国在1959年修建的AASHO试验环道支撑了世 界著名的AASHO路面设计指南的诞生 ${ }^{[2,3]}$, 又于 20 世纪 90 年代先后修建了明尼苏达环道MnROAD ${ }^{[4]}$ 、美国西 部环道Westrack ${ }^{[5]}$ 和美国国家沥青技术中心NCAT环 道 ${ }^{[6,7]}$, 开展了长达 30 余年的跟踪观测和试验研究. 法国 自1984年开始依托南特环道开展大量的路面加速加载 试验, 不断验证、完善法国路面设计方法 ${ }^{[8,9]}$. 20 世纪70
年代初, 南非通过室外大型的加速加载设备开展半刚 性基层沥青路面结构研究 ${ }^{[10,11]}$, 取得了至今仍具有世 界影响力的研究成果. 我国自 20 世纪 80 年代中期开始 类似试验研究，取得的成果对于支撑超大规模国家公 路网建设技术和质量的快速提升起到了重要作用.

1998年，为了实现公路全寿命周期内技术经济最 优化，欧美国家首先提出长寿命路面理念作为未来发 展目标, 但至今尚未提出完善的设计方法体系. 与现有 路面相比, 长寿命路面的实际使用寿命将延长2倍, 需 要验证既有以线弹性层状理论体系为基础的路面设计 方法、模型和指标的适用性、可靠性，并以此为基础， 研发适用于长寿命路面的新一代路面设计方法. 开展 足尺路面加速加载试验及长期性能跟踪观测，系统积 
累多场耦合条件下多元路用性能演化的科学数据, 探 求沥青路面超长服役周期条件下的行为规律和损伤破 坏机理, 是加快推动这一新命题破解的有效手段和 平台.

2015年11月，我国建成世界首条以长寿命沥青路 面全寿命周期服役性能验证为目标的, 宽刚度域基层 结构的足尺路面环道—RIOHTrack(Research Institute of Highway MOT Track ${ }^{[12]}$, 使我国具备了全方位获取 沥青路面全寿命周期多元服役性能演化信息的能力, 为弥补长期制约我国路面学科创新发展的科学基础数 据短板创造了条件. 本文将主要介绍该环道试验 4 年来 的运行情况, 以及发现的新规律及研究进展.

\section{1 足尺加速加载试验现状}

自1920年荷兰东印度公路协会修建环道型足尺试 验路开始 ${ }^{[1]}$, 足尺加速加载试验在路面技术近百年发展 历程的不同阶段均发挥了重要作用. 路面加速加载试 验设施、设备形式多样 ${ }^{[13 \sim 16]}$, 可分为 4 类: 大型移动 式、室内试槽模式、野外小型加速加载环道和野外大 型加速加载环道.

\section{1 国外加速加载试验现状}

表1为国外主要加速加载试验装置的主要技术特 点及典型代表研究机构. 其中, 如AASHO、NCAT等采 用实车加载的野外大型足尺试验路, 是试验效率最高, 当然也是试验成本最高的类型.

欧美国家足尺加速加载试验研究历程体现了鲜明 的技术需求和时代背景. 以美国为例, 20 世纪 50 年代末
期的AASHO试验路, 主要以解决路面设计中的轴载标 准、轴载换算方法、路面破坏标准、性能预估模型等 关键问题为目标, 利用其核心成果制定出AASHO路面 设计指南. 该指南不仅支撑了美国国家公路网的大规 模建设, 而且影响了世界路面技术的发展. 20 世纪 80 年 代末期, 美国国家公路网基本建成, 新材料开发及材料 设计方法的研究逐步成为热点需求, 因此, 20世纪90年 代建成的Westrack主要面向基于功能需求的Superpave 沥青混合料设计方法的验证与评估. 到 20 世纪 90 年代 后期，美国又针对既有路面“经验法”设计的不足和局 限性, 开展了基于性能的路面 “力学-经验法” (即 MEPDG2002)设计的研究, 并依托MnROAD和NCAT两 个大型足尺路面试验环道验证相关的设计模型和指标. 21世纪以来, 随着长寿命路面理念的提出, NCAT环道 围绕疲劳极限、平衡设计等核心技术问题, 已开展了 持续20年的试验研究, 通过监测沥青路面结构内部应 力、应变响应, 探讨长寿命路面的层底拉应力阈值, 证 明由室内材料疲劳试验提出的 70 微应变 ${ }^{[15,16]}$ 疲劳标准 阈值偏低, 从而将导致路面结构设计厚度偏高, 该研究 结果对于优化路面结构设计起到了重要指导作用.

总之, 开展足尺路面的加速加载试验是路面技术 发展不可或缺的重要技术手段, 其最终目标是利用加 速模拟所获得的信息、数据, 揭示路面行为规律及其 影响因素, 构建和验证设计理论与预估模型.

\section{2 我国加速加载试验现状}

随着我国路面技术的发展，1984和1985年交通部 重庆公路科学研究所和东南大学先后建成我国首批室

表 1 国外加速加载试验装置类型及主要参数比较 ${ }^{a)}$

Table 1 Comparison of types and main parameters of foreign accelerated loading test facilities

\begin{tabular}{|c|c|c|c|c|c|c|c|}
\hline 类型 & 可同步试验结构 & 测试结构 & 环境控制 & 荷载模式 & $\begin{array}{l}\text { 加载 } \\
\text { 效率 }\end{array}$ & $\begin{array}{l}\text { 试验 } \\
\text { 成本 }\end{array}$ & 典型代表 \\
\hline 大型移动式 & $1 \sim 2$ & 足尺、缩尺 & 可控 & 实轮 & + & + & 澳大利亚ALF(1961年至今) \\
\hline 室内试槽, 模式装置 & $2 \sim 10$ & 缩尺 & 可控 & 实轮 & ++ & + & $\begin{array}{c}\text { 美国民航局FAA(1999年至今) } \\
\text { 荷兰代尔夫特(1990年至今) }\end{array}$ \\
\hline 野外小型, 环道 & $2 \sim 10$ & 缩尺为主 & 自然环境 & 实轮 & ++ & ++ & 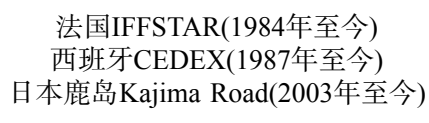 \\
\hline 野外大型, 足尺环道 & $20 \sim 40$ & 足尺 & 自然环境 & 实车 & +++ & +++ & $\begin{array}{c}\text { AASHO环道(1958 1961年) } \\
\text { Westrack环道(1994 1999年) } \\
\text { NCAT环道(2000年至今) } \\
\text { MnRoad(1990年至今) }\end{array}$ \\
\hline
\end{tabular}

a) “+”表示量的多少, “+”越多表明效率及成本越高, 但“+”的数量并不具有定量的倍数关系 
内试槽模式的加速加载试验装置 ${ }^{[17 ~ 21]}$. 1989年, 交通部 公路科学研究所从澳大利亚引进我国第一台可用于野 外实际工程的大型加速加载设备(accelerated loading facility, ALF $)^{[22]}$. 经过 30 年的发展, 目前我国各类机构 拥有各类大型加速加载装置(设施)超过10台(表2).

在前期研究中，主要依靠移动式和室内小型环道 加速加载设备进行试验，先后开展了半刚性基层路面 结构与材料性能的研究、路面结构组合方式比较研 究、国外引进的多种路用材料设计标准研究以及钢桥 面铺装结构行为研究等 ${ }^{[23 \sim 26]}$, 在评价路面材料性能、 修正路面结构设计参数、研究特殊结构行为等方面取 得了重要成果. 但ALF、MLS及HVS设备采用半轴单轮 或双轮往复加载, 加载速度一般低于 $30 \mathrm{~km} / \mathrm{h}$. 在时间和 经济成本的双重制约下，采用该类加速加载试验的研 究一般都仅能够完成百万级累计轴次加载, 部分研究 中采用折减结构厚度等效的方式，折算成较高轴次的 寿命周期，但难以实现路面全寿命周期的全尺寸结构 模拟. 另一方面，由于该类设备的行程有限，通常仅能 在几米至十几米范围内开展同步试验，结构类型、结 构段有效长度均非常有限，难以同步获得多样性的结 构、材料类型间差异化的响应特征. 受制于上述两方 面条件, 尚需开展野外大型足尺加速加载试验，以获得 长寿命路面设计体系革新所需的超长周期演化数据.

2015年11月建成的RIOHTrack环道是世界上第一 条以长寿命沥青路面服役性能设计模型验证为目标的 足尺路面试验环道，该环道修筑了19种不同结构形式 的沥青路面, 涵盖了国内外典型的路面结构, 也是世界 上第一条宽刚度域基层的足尺路面试验环道。通过 5000 万当量轴次的实车加速加载试验, 不仅可以客观 比较不同路面结构服役性能的差异，而且将在世界上 首次同步获得宽刚度域沥青路面结构全寿命周期的多 元服役性能演化数据，为设计理论体系的革新提供验 证的基础条件.

\section{RIOHTrack环道研究现状}

\subsection{RIOHTrack环道概况}

RIOHTrack足尺路面环道的19种结构如图1所示, 包括薄沥青层半刚性基层路面STR1 STR3、常规半刚 性基层路面STR6 STR9、刚性复合式路面STR4 STR5、倒装结构路面STR10和STR12、厚沥青结构路 面STR11和STR13 STR17及全厚式结构路面STR18和
表 2 我国加速加载试验装置(设施)情况

Table 2 China's accelerated loading test equipment (facilities)

\begin{tabular}{|c|c|}
\hline 类型 & 典型代表 \\
\hline 大型移动式 & $\begin{array}{l}\text { 交通部公路科学研究所(1990年至今)ALF; 辽宁省交 } \\
\text { 通科学研究院(2009年至今)、长沙理工大学(2017年 } \\
\text { 至今)MLS(Mobile Load Simulator); 长安大学(2007 } \\
\text { 年至今)、同济大学(2017年至今)、江苏省交通科学 } \\
\text { 研究院股份有限公司(2019年至今)HVS(Heavy Vehi- } \\
\text { cle Simulator) }\end{array}$ \\
\hline 室内固定式 & $\begin{array}{c}\text { 交通部重庆公路科学研究所(1984年至今); 东南大学 } \\
\text { (1985年至今); 长沙理工大学(1999年至今) }\end{array}$ \\
\hline 野外小型 & 北京科技大学国家材料科学服役中心(2019年至今) \\
\hline 野外大型 & 交通运输部公路科学研究院RIOHTrack(2015年至今) \\
\hline
\end{tabular}

STR19六种类型. 路面结构的总厚度为 $68 \sim 100 \mathrm{~cm}$ 不等. 共包括 21 种沥青混合料面层和基层材料、5种水泥稳 定材料和 1 种级配碎石基层材料，组合而成具有宽刚度 域基层的19种路面结构 ${ }^{[12]}$.

环道采用封闭式、拖挂卡车加载，每天日间连续 运行 $12 \mathrm{~h}$ ，平均车速为 $40 \sim 50 \mathrm{~km} / \mathrm{h}$. 自2016年12月起加 载，先后采用了两种模式，2017和2018年采用模式一， 加载车轴重及轴型如图2(a), 自2019年起, 改为采用如 图2(b)所示的模式二. 环道的性能检测包括实时监测和 周期性检测两种类型，其中，实时监测包括以 $2000 \mathrm{~Hz}$ 频率全天候采集结构内部应力、应变信息, 感应式车 辆轴载监测以及结构内外环境监测等，至今已累计采 集数据达 $360 \mathrm{~Tb}$, 传感器类型、位置及精度信息见表 3 . 另一类为周期性检测，包括结构承载能力、表面功 能、破损及服务能力等指标的检测，截至2020年1月 底，已累计完成 74 个周期，检测样本量达 48 万个．以海 量数据采集和分析为基础, 表征路面性能演化规律, 以 及典型沥青路面结构间性能的显著差异性.

\section{2 环道研究现状与思考}

RIOHTrack至今已运行4年，完成累计当量轴载作 用 2400 万次，相当于实际重载交通条件下 12 15年使用 寿命. 期间, 通过定期采集多元化的服役性能演化数据, 发现了一些有价值的现象, 主要包括: 路面的服役性能 是随荷载与环境(主要是温度)同步耦合作用产生衰变 的，而不是单纯地依赖荷载作用; 路面结构形式的差异 对服役性能演化规律的影响显著，服役性能存在显著 的结构依赖性. 由现象学的发现出发, 从沥青路面非线 性力学体系研究和大数据分析、挖掘角度人手，探究 了沥青路面服役性能的演化机理，构造了新型的服役 


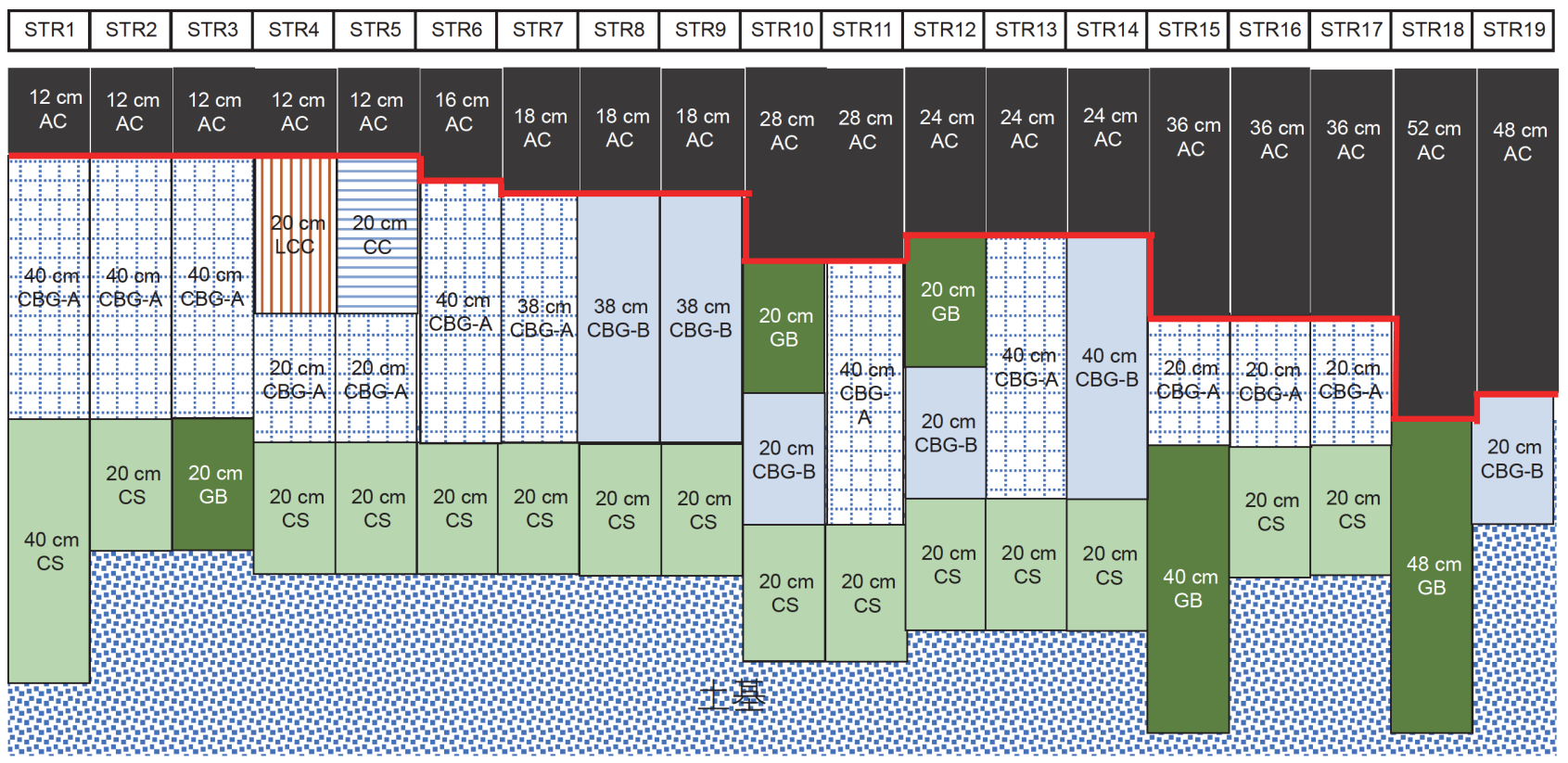

图 1 RIOHTrack足尺环道路面结构示意图. AC: 沥青混凝土; CBG-A: 水泥稳定级配碎石材料, 设计7 d无侧限抗压强度为6 MPa; CBG-B: 水泥 稳定级配碎石材料, 设计 $7 \mathrm{~d}$ 无侧限抗压强度为 $4.5 \mathrm{MPa}$; CS: 水泥稳定土, 设计 $7 \mathrm{~d}$ 无侧限抗压强度为 $2 \mathrm{MPa}$; LCC: 贫混凝土, 设计 $7 \mathrm{~d}$ 无侧限抗压 强度为 $8 \mathrm{MPa}$; CC: 水泥混凝土; $\mathrm{GB}$ : 级配碎石

Figure 1 Diagram of the RIOHTrack pavement structures. AC, asphalt concrete; CBG-A, cement bond graded stone ( $7 \mathrm{~d}$ unconfined compression strength is $6 \mathrm{MPa}$ ); CBG-B, cement bond graded stone ( $7 \mathrm{~d}$ unconfined compression strength is $4.5 \mathrm{MPa}$ ); $\mathrm{CS}$, cement soil ( $7 \mathrm{~d}$ unconfined compression strength is $2 \mathrm{MPa}$ ); LCC, lean cement concrete ( $7 \mathrm{~d}$ unconfined compression strength is $8 \mathrm{MPa}$ ); $\mathrm{CC}$, cement conctrete; GB, graded broken stone
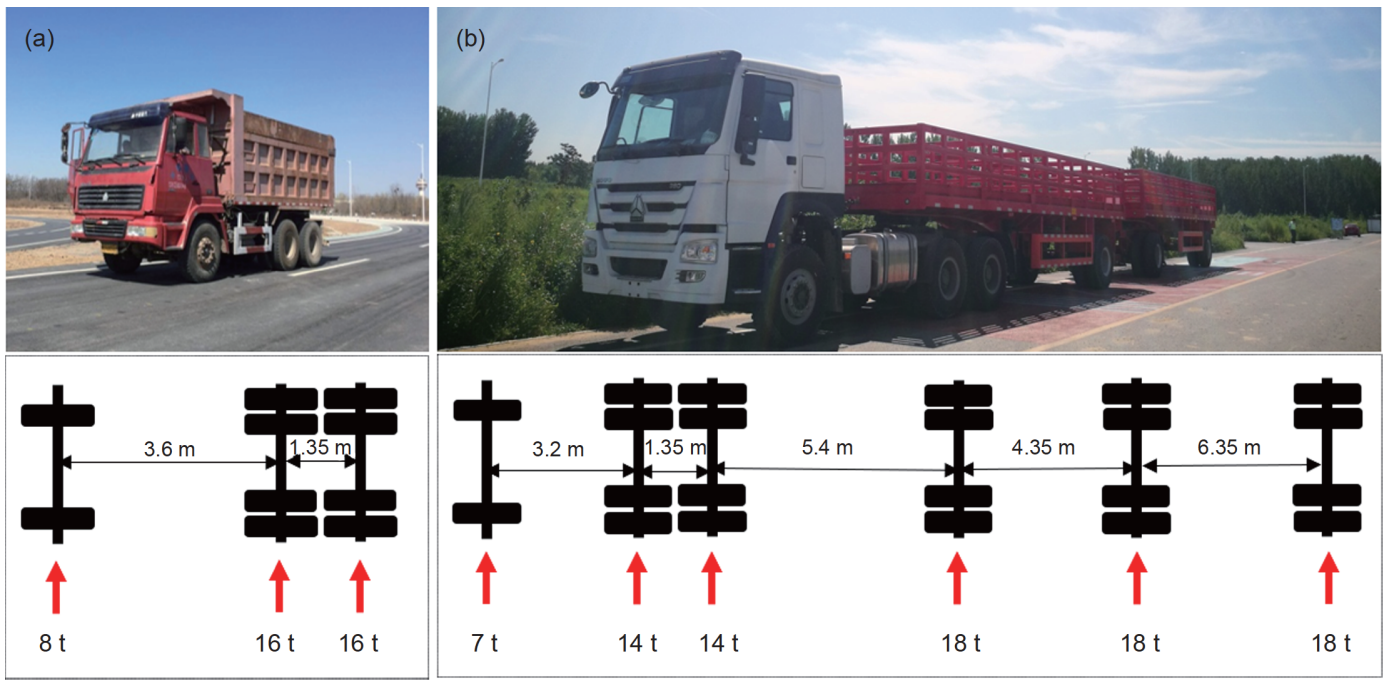

图 2 加载车轴重及轴型分布. (a) 加载模式一; (b) 加载模式二

Figure 2 Axle weight and axle distribution of the load trucks. (a) Loading model I; (b) loading model II

性能演化模型, 取得了初步的进展.

\subsection{1 荷载与环境的同步耦合效应对服役性能的影响}

路面在服役期间不断承受来自交通荷载和自然环 境变化的耦合作用，这一耦合效应构成了路面服役性
能复杂性的外在因素. 图3(a)，(b)分别汇总了2016 2019年4年间的FWD(falling weight deflectometer)落锤 弯沉和车辙深度的74次周期性检测结果, 其中FWD落 锤弯沉盆面积结果来自44400个弯沉盆检测数据, 车辙 
表 3 RIOHTrack环道监测主要传感器及其技术参数

Table 3 Main types and technology parameters of sensor used in RIOHTrack

\begin{tabular}{|c|c|c|c|c|c|}
\hline 类型 & 测试原理 & 测量范围/精度 & 采样频率 & 埋设位置及布置方式 & 温度范围 $\left({ }^{\circ} \mathrm{C}\right)$ \\
\hline 沥青层应变 & 电阻应变式 & $-5000 \sim+5000 \mu \varepsilon / 1 \%$ & $2000 \mathrm{~Hz}$ & 各结构路段的沥青层间/矩阵布置 & $-20 \sim+80$ \\
\hline 水稳层应变 & 电阻应变式 & $-5000 \sim+5000 \mu \varepsilon / 1 \%$ & $2000 \mathrm{~Hz}$ & 各结构路段的水稳层层间/矩阵布置 & $-20 \sim+80$ \\
\hline 压应力 & 电阻应变式 & $0 \sim 500 \mathrm{kPa} / 0.1 \%$ & $2000 \mathrm{~Hz}$ & 各结构路段的沥青层、水稳层层间、土基顶面/矩阵中心 & $-10 \sim+55$ \\
\hline 动态称重 & 压电传感器 & $0 \sim 30 \mathrm{t}, 5 \sim 180 \mathrm{~km} / \mathrm{h}$ & & 环道K0+000断面, 行车道 $2 \mathrm{~m} \times 2 \mathrm{~m}$ 正方形线圈 & \\
\hline 温度 & 铂电阻 & $-50 \sim 100^{\circ} \mathrm{C} / \pm 0.3^{\circ} \mathrm{C}$ & $10 \mathrm{~min}$ & 各结构路段的沥青层、水稳层层间、土基不同深度处 & $-50 \sim 100$ \\
\hline 湿度 & 频域反射 & $0 \sim$ 饱和 $/ \pm 3 \%$ & $1 \mathrm{~h}$ & 各结构路段的沥青层、水稳层层间、土基不同深度处 & 0 饱和 \\
\hline
\end{tabular}
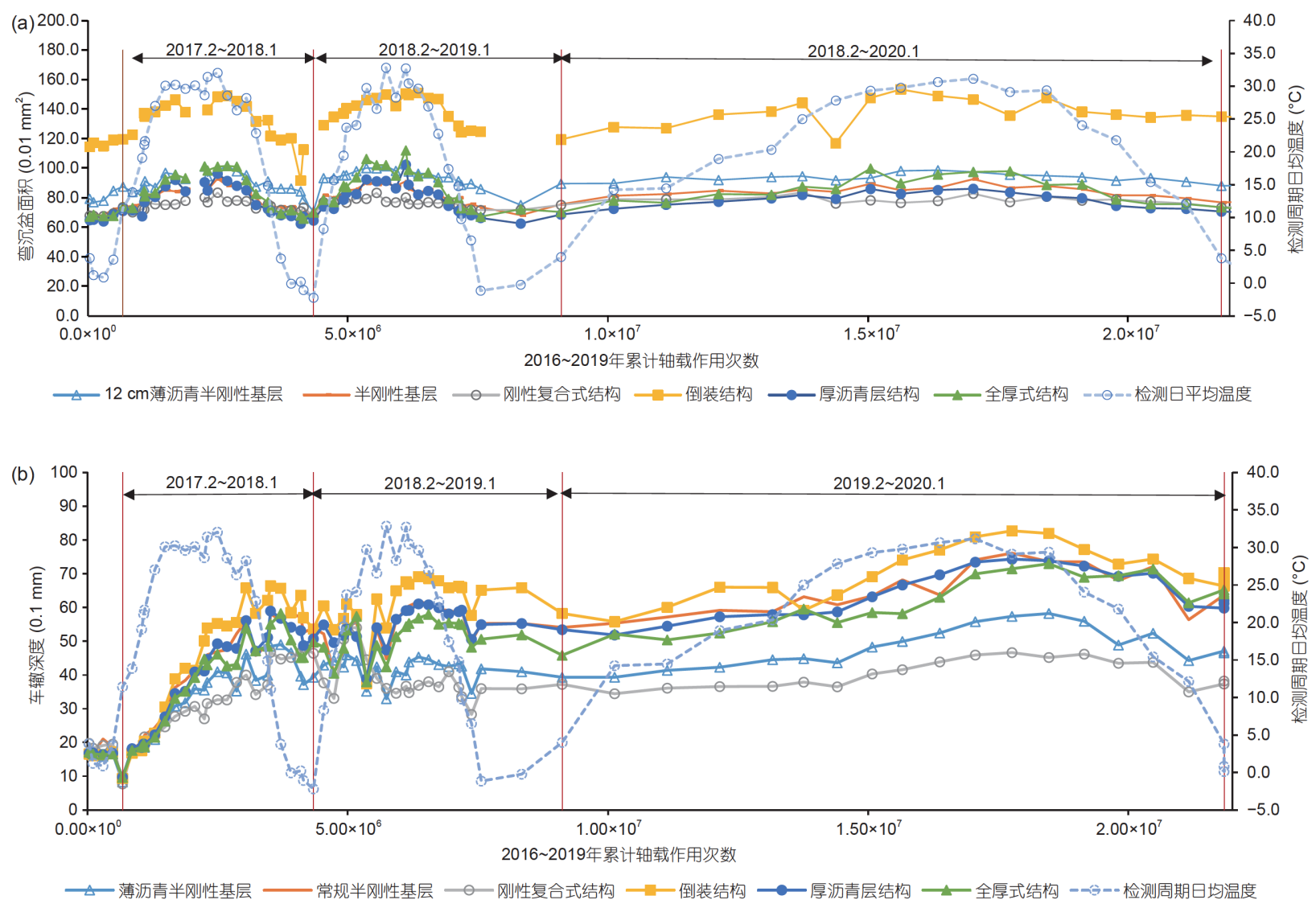

图 3 RIOHTrack 6类结构路段弯沉盆和车辙深度实测结果. (a) 弯沉盆; (b) 车辙深度

Figure 3 Measured results of the deflection basin area and the rutting depth for all the 6 types structures in RIOHTrack. (a) The deflection basin; (b) the rutting depth

深度结果来自 14800 个车辙检测点数据. 可以看出, 当 不考虑温度修正时，弯沉盆面积与年温度变化趋势有 较好的一致性. 截至目前, 温度是弯沉盆面积的首要影 响因素. 进行温度修正后，分别统计最后 5 个检测周期 与最初 5 个周期弯沉盆面积均值, 则在经历了 2400 万轴 载作用后, 6 类结构的弯沉盆面积有 $4.4 \% \sim 15.3 \%$ 不等的 增长, 平均增长率为 $10.0 \%$. 车辙深度曲线则由荷载应
力产生累计变形增长与温度应力产生的正弦式波动叠 加，虽总体呈现增长趋势，但在年周期内，并非单调增 加, 而是存在随温度下降而减小的递减段. 服役性能呈 年周期变化, 环境温度的影响显著且不可忽略.

\subsection{2 宽刚度域路面结构路用性能的结构依赖性}

图3不仅展现了荷载与温度耦合效应对路用性能 影响，而且，6类不同结构间承载能力和使用功能表现 
的差异说明在相同的荷载和温度耦合作用下，路用性 能具有典型的结构依赖性. 以车辙深度指标为例, 统计 全部74周期所有结构的车辙深度均值作为基准值, 然 后分别计算6类结构各自的均值与基准值的偏差，如图 4柱状图所示, 可见车辙深度在不同结构间存在明显差 异. 同理, 按照同样方法统计弯沉盆面积、平整度指数 等指标. 进一步采用相同权重计算各类结构 3 项指标偏 差的均值来综合评价总体路用性能，如图4斜线柱状图 所示. 可以看出, 在相同的荷载与环境作用下, 倒装结 构和厚沥青层结构之间总体路用性能差异最大，差值 近 $20 \%$, 说明不同路面结构具有各自典型的服役性能 演化规律和特点, 需要建立不同结构的针对性性能评 价模型.

采用2017版沥青路面设计规范和MEPDG2000设 计指南的车辙预估模型，对环道19种结构试验段不同 荷载作用次数下的车辙深度进行预估，并与车辙实测 结果进行比较. 图 5(a), (b)的曲线为对应各结构两种模 型预估结果与实测结果误差绝对值的均值, 柱状图则 为 74 个检测周期数据误差绝对值的变化范围. 可见, 总 体而言，按照2017版路面设计规范计算的19种不同结 构相对误差绝对值的均值波动在 $16.91 \% \sim 44.09 \%$ 之间， 明显小于MEPDG2000预估偏差. MEPDG2000设计指 南车辙预估模型的精度随路面结构差异具有显著差别, 对于薄沥青面层的半刚性和刚性复合式基层类结构误 差和误差的变异范围最大，相对误差绝对值的平均值 高达 $100 \%$ 以上，而对于包含级配碎石层的STR 10 、
STR12、STR15和STR18，误差绝对值的平均值和变异 范围均接近于 2017 版设计规范的预估结果. 总体上看, 2017版设计规范的预估模型更加适用于我国包含半刚 性基层的路面结构.

\subsection{3 沥青路面非线性力学体系的初步构建}

荷载与环境同步耦合作用下，结构内部力学响应 特征的不同是路面结构间服役性能差异的内在原因. 受荷载、环境、组成材料等因素影响，沥青路面服役 过程中的非线性结构响应特征尤其显著，而现有理论 分析中线性假设只是实际问题的一种简化处理. 因此, 不断完善路面力学体系，合理表达实体结构中的力学 响应状态, 是路面学科研究的基础理论问题.

为此, 环道研究过程中, 利用足尺路面环道实测研 究构建了沥青混合料、水泥稳定碎石及路基土等 3 类 典型路面材料多模态模量应力依赖模型 ${ }^{[27]}$. 基于Mises 等效应力将模型中的单一应力状态与实体结构中的复 杂应力状态进行联系，作为材料模量到结构模量跨越 的联系机制，提出基于材料非线性的沥青路面结构分 析当量迭代计算方法. 并通过实体结构海量的应力、 应变响应数据对比，验证了新力学方法的合理性和可 靠性.

选择夏季代表性温度条件，对比RIOHTrack足尺 环道代表性半刚性基层结构STR1和全厚式结构STR19 路段的实测应变响应数据与计算结果. 图6是在 $5 、 7 、$ 9、11 t落锤荷载作用下，沥青层底应变响应实测值与 理论计算结果之间的相关关系. 结果表明, 即便是路面

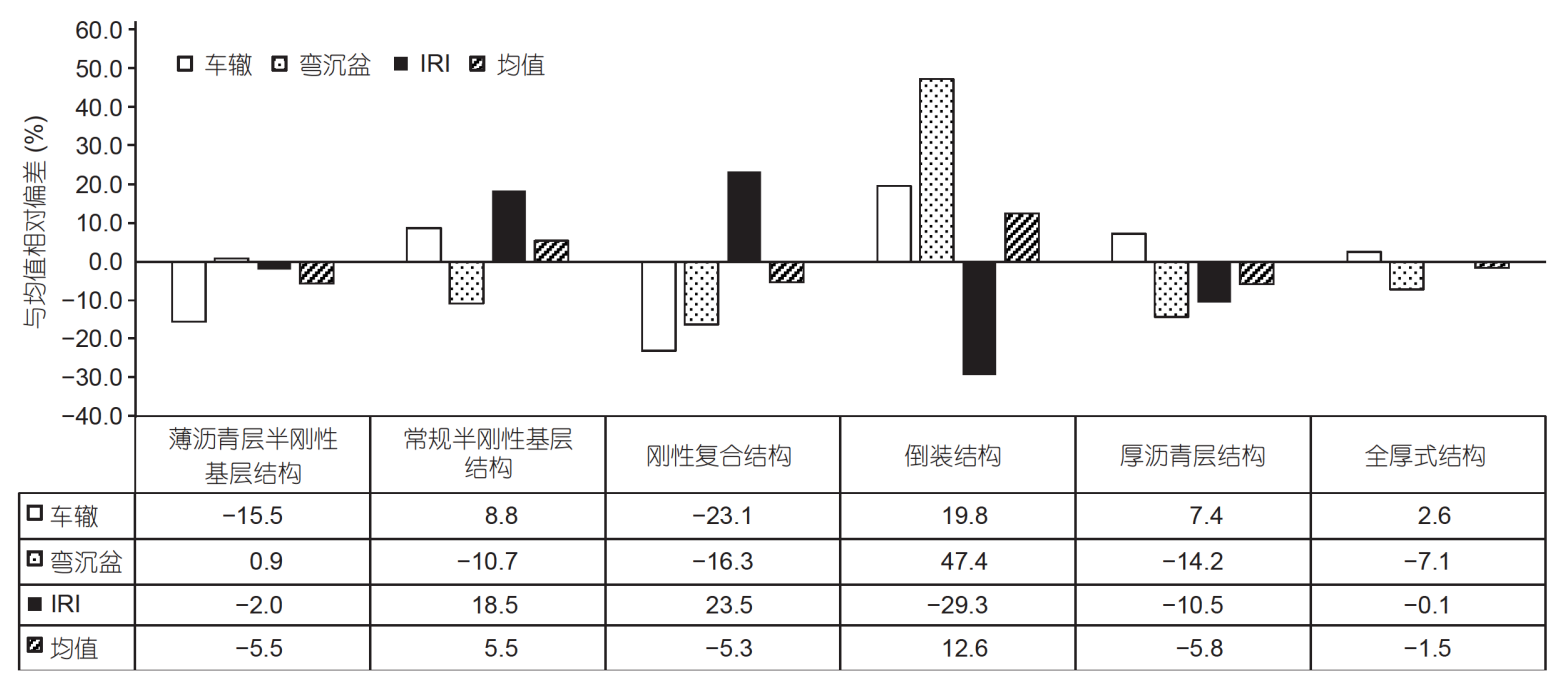

图 4 RIOHTrack各类路面结构路用性能均值偏差统计

Figure 4 Mean deviation statistics for the pavement performance of various structures in RIOHTrack 

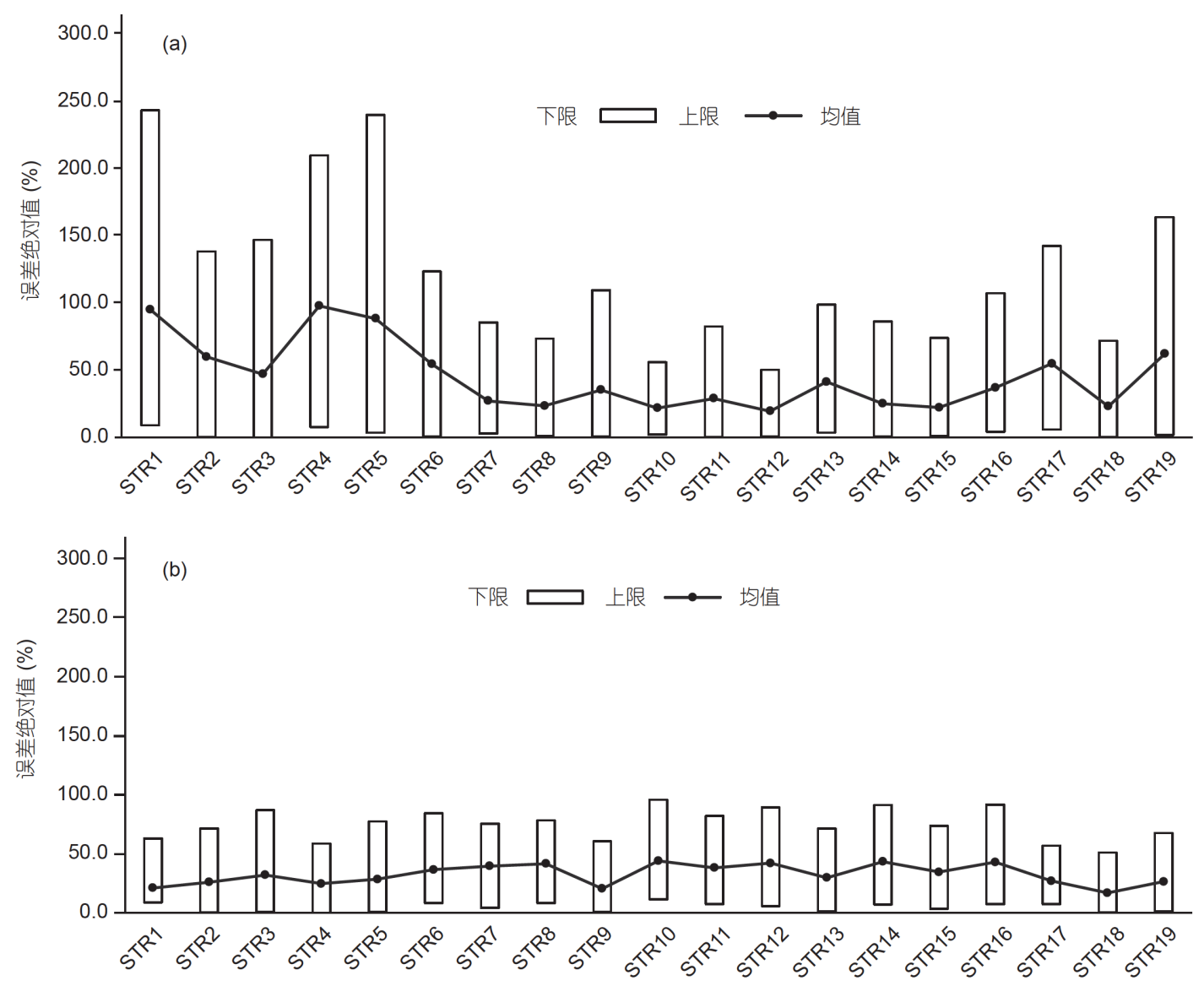

图 5 RIOHTrack路面结构车辙实测与预估结果的误差绝对值统计. (a) MEPDG2000指南; (b) 2017版沥青路面设计规范(JTG D50-2017)

Figure 5 Statistics of error absolute value of measured and predicted rutting depth of RIOHTrack pavement structures. (a) MEPDG2000; (b) Specifications for Design of Highway Asphalt Pavement JTG D50-2017
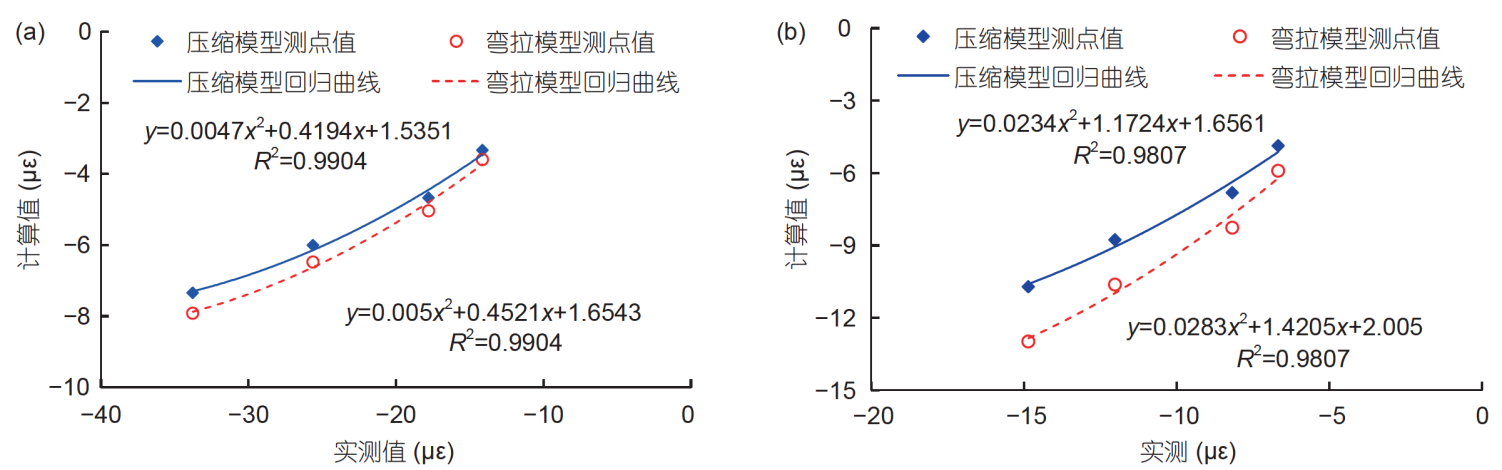

图 6 (网络版彩色)夏季沥青面层层底横向应变实测值与计算值对比图. (a) STR1; (b) STR19

Figure 6 (Color online) Comparison of measured and calculated transverse strain of asphalt layer bottom in summer. (a) STR1; (b) STR19

结构非线性特征最为突出的夏季, STR1和STR19的沥 青面层层底应变的计算结果与实测结果仍具有较好的 相关关系，可分别采用二次函数和对数函数进行回归， 决定系数 $R^{2}$ 均能够达到 0.97 以上, 说明虽然计算值与
实测值在数值上并不完全相等，但两者具有稳定的 关系.

另外，环道实体路面结构响应系统的跟踪观测显 示，沥青路面实际服役中存在明显的材料非线性和几 
何非线性共存现象 ${ }^{[28]}$ ，不仅应力-应变关系为非线性, 位移-应变关系也呈非线性变化. 因此, 进一步考虑引 人几何非线性问题，初步构建了材料非线性与几何非 线性耦合的新型沥青路面力学分析体系. 借鉴非线性 固体力学中的相关研究方法, 用有限变形假设代替小 变形假设, 通过公式推导建立基于物质描述的有限变 形条件下弹性体系的平衡方程、应力张量增量方程、 几何方程、本构方程、边界条件等控制方程，采用位 移函数法建立了有限变形条件下弹性体系应力、应 变、位移的求解体系，进而获得考虑材料和几何非线 性影响的路面分析结果. 初步计算结果表明, 与线性假 定相比, 考虑双重非线性后: (1) 坚向位移显著增大, 数 值上约增加 $60 \%$, 路面结构受力更加不利. (2) 各个结 构层中的Mises等效应力出现了重新分布. 其中, 沥青 面层内部的等效应力明显变大, 受力更为不利. (3) 在 结构层层间位置处的水平径向应力出现了方向的改 变, 线性结果为压应力, 而双重非线性下的计算结果则 为拉应力, 此时相应的路面结构层层底更容易出现 开裂.

目前, 对于材料与几何双重非线性下的路面力学 问题, 仅进行了一些探索性研究工作, 仍需结合足尺环 道的持续跟踪观测数据验证该方法的可靠性.

\subsection{4 路面服役性能模型的大数据分析}

足尺环道技术团队历时 4 年所采集的海量数据为 构建性能预估模型提供了初步条件. 如前文所述荷载 与环境的堣合效应是路面性能的外在因素, 考虑两大 影响因素的预估模型构建通常有3套思路: 一是变量分 离方法, 首先构建服役性能的温度修正模型, 再建立荷 载作用的演化模型; 二是通过多因素的神经网络自学
习方式构建隐式模型; 三是基于非线性多元统计回归 方法构建显式模型.

由于篇幅所限, 本文仅展开介绍按照非线性多元 统计回归方法构建车辙预估模型的实践. 为了建立更 加符合足尺环道车辙周期性变化规律的显示化车辙预 估模型, 基于统计分析将荷载和温度作为自变量, 将车 辙深度作为因变量, 尝试构造了 4 种显示化车辙预估模 型表达式, 见式(1). 并根据足尺环道的车辙、温度和累 计轴次观测结果, 以已有的 14400 个检测数据结果为基 础, 对 4 种显示化模型的参数进行标定. 利用实际观测 数据, 采用 $1 \mathrm{stOpt}$ 软件, 对 4 类车辙预测模型, 随机设定 初始值, 通过Levenberg-Marquardt算法找出各系数的最 优解:

$$
\begin{aligned}
\mathrm{RD}= & a \cdot \lg N+b \cdot \sin (c \cdot T)+d, \\
\mathrm{RD}= & a \cdot(\lg N)^{b}+c \cdot \sin (d \cdot T)+e, \\
\mathrm{RD}= & a \cdot \lg N+b \cdot \sin (c \cdot T) \\
& +d \cdot \lg N \cdot \sin (c \cdot T)+e, \\
\mathrm{RD}= & a \cdot(\lg N)^{b}+c \cdot \sin (d \cdot T) \\
& +e \cdot \lg N \cdot \sin (d \cdot T)+f,
\end{aligned}
$$

式中, $\mathrm{RD}$ 为车辙深度, $0.1 \mathrm{~mm} ; N$ 为累计标准轴载作用 次数; $T$ 为路表实测温度, ${ }^{\circ} \mathrm{C}$.

4 个模型对于实测车辙数据的拟合精度汇总于表 4 . 由拟合精度结果可见, 模型 3 和模型 4 对于环道路面结构 具有更好的适用性. 图7(a) (f)分别绘制了6类结构代表 试验路段的车辙实测结果, 2017版沥青路面设计规 范、MEPDG2000指南和足尺环道预估模型结果. 采用

\begin{tabular}{|c|c|c|c|c|c|}
\hline \multirow{2}{*}{\multicolumn{2}{|c|}{ 路面结构类型 }} & \multicolumn{4}{|c|}{ 相关系数 $R^{2}$} \\
\hline & & \multirow{2}{*}{$\begin{array}{l}\text { 模型1 } \\
0.582\end{array}$} & \multirow{2}{*}{$\begin{array}{l}\text { 模型2 } \\
0.571\end{array}$} & \multirow{2}{*}{$\begin{array}{c}\text { 模型3 } \\
0.684\end{array}$} & \multirow{2}{*}{$\begin{array}{c}\text { 模型4 } \\
0.689\end{array}$} \\
\hline 薄沥青层半刚性基层结构 & STR $1 / 2 / 3$ & & & & \\
\hline 常规半刚性基层结构 & STR6/7/8/9 & 0.628 & 0.630 & 0.780 & 0.783 \\
\hline 刚性复合结构 & STR4/5 & 0.382 & 0.389 & 0.426 & 0.436 \\
\hline 倒装结构 & STR10/12 & 0.632 & 0.628 & 0.738 & 0.783 \\
\hline 24 28 cm厚沥青结构 & STR11/13/14 & 0.629 & 0.611 & 0.748 & 0.752 \\
\hline $36 \mathrm{~cm}$ 厚沥青结构 & STR15/16/17 & 0.650 & 0.667 & 0.816 & 0.817 \\
\hline 全厚式结构 & STR18/19 & 0.635 & 0.654 & 0.786 & 0.787 \\
\hline
\end{tabular}
模型4进行预估, 考虑年温度变化影响的车辙发展趋势 具有更好的拟合度, 但仍需要通过观测数据的积累进 一步验证和修正模型与参数, 并在模型中引人结构类

\section{表 4 4种显示化车辙预估模型拟合精度统计}

Table 4 Fitting accuracy of four kinds of displayed rutting prediction models 

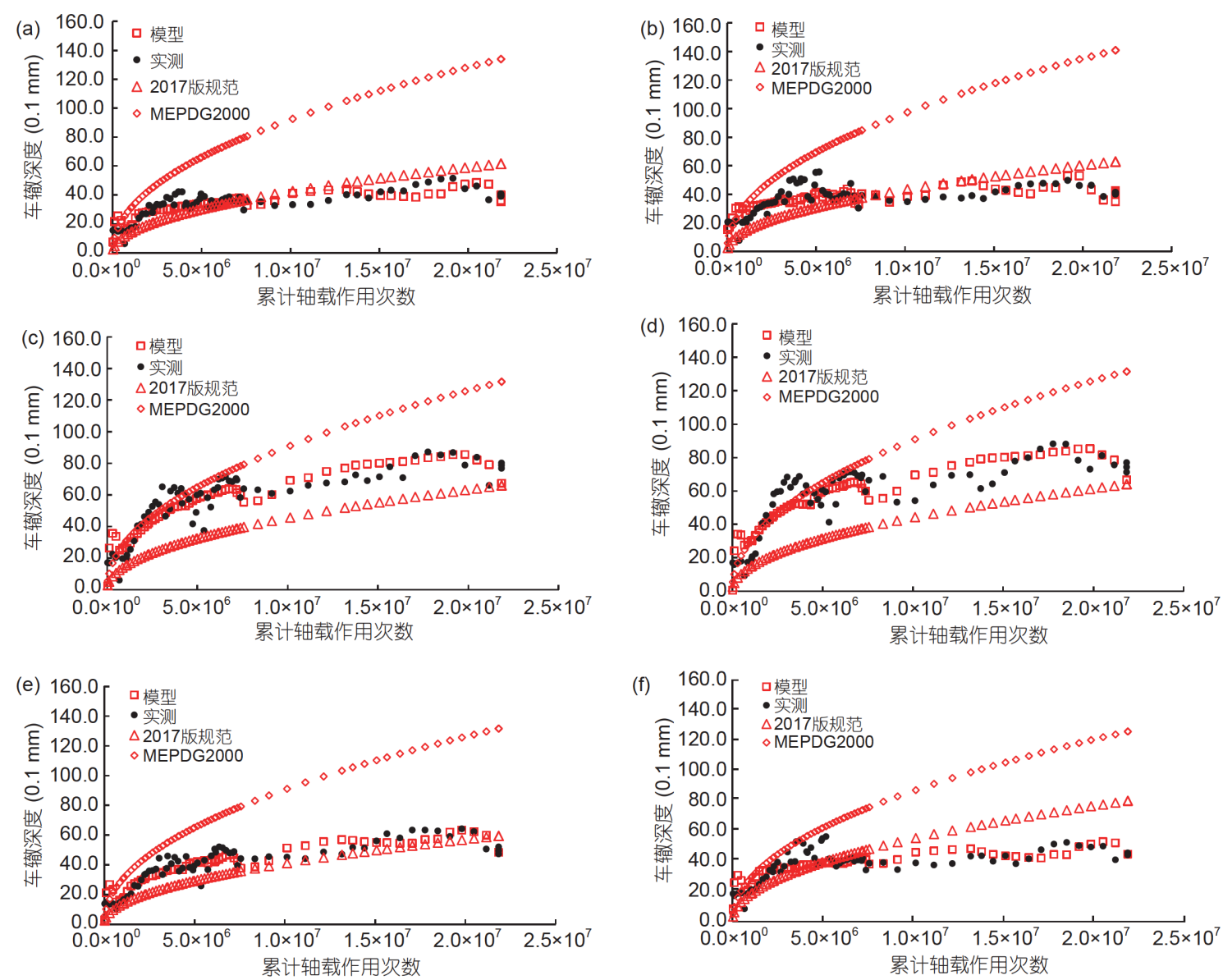

图 7 (网络版彩色)RIOHTrack路面结构车辙实测与预估结果. (a) STR1; (b) STR5; (c) STR7; (d) STR10; (e) STR17; (f) STR19

Figure 7 (Color online) Comparison of the prediction and measured rutting depth results. (a) STR1; (b) STR5; (c) STR7; (d) STR10; (e) STR17; (f) STR19

型因子.

\section{3 总结}

在科学探索和技术研发中，新现象的发现和新方 法的建立通常依赖于观测技术或手段的发展与应用. 足尺加速加载试验研究实施虽然技术难度高、投人大, 但其在揭示多因素耦合作用下路面长期服役行为规律 上的优势, 是其他研究方式无法比拟的, 无疑是在较短 时间内完成全寿命周期评估与验证的最为有效手段, 是揭示路面复杂行为特征的基础条件之一. 我国选择 半刚性基层路面结构作为国家公路网主要结构形式有 其经济、历史和技术背景，历经 40 余年，近 500 万千米 的应用, 已建成了世界上最大规模的国家公路网, 在世 界上独树一帜，在此基础上发展长寿命路面技术是适 合我国的选择. 因此, 应集中国内现有加速加载装置和 机构的力量, 优化顶层设计、开展协作研究, 充分利用
足尺加速加载环道真实加载、高频率监测与检测的优 势, 推进路面结构与材料由损伤-破坏过程机理的研究, 并结合国家公路野外科学观测网的建设，将足尺环道 形成的自动化监测、检测以及数据分析方法扩展至不 同使用条件, 形成对不同气候条件的补充, 弥补足尺环 道在环境多样性方面的不足，尽快提出我国长寿命沥 青路面设计理论与方法体系.

RIOHTrack足尺路面环道从获取路面服役行为的 现象学特征人手，充分证明了在长寿命路面服役过程 中路面结构与材料的非线性特征是不容忽视的，是改 进现有设计方法体系的基础. 立足于材料的结构行为, 构建材料与结构间的联系机制，提出了基于材料结构 行为的沥青路面非线性力学分析体系; 基于对荷载与 环境耦合效应影响的解析，初步构建了多元服役性能 预估模型等，取得了一定的技术进步. 当然，目前的成 果尚需要持续观测数据的不断校验和修正. 进一步将 
在现有成果基础上, 遵循发现现象-提出理论-实践验证 的脉络, 通过不断循环推进的方式完善力学分析体系
和性能预估模型，逐步推进新一代长寿命路面设计方 法的研发.

\section{参考文献}

1 Metcalf J B. A brief history of full-scale accelerated pavement testing facilities to 1962. In: Jose P A, Adriana V N, Fabricio L V, et al., eds. In: Proceedings of the International Conference on Accelerated Pavement Testing. Switzerland: Springer International Press, $2016.3-16$

2 Fred B, Elmer M W, Herbert P O. The AASHO Road Test History and Descreiption of Project. Special Report 61A. Technical Report, National Academy of Sciences-National Research Council, 1961

3 Woods K B. The AASHO Road Test Summary Report. Special Report 61G. Technical Report, National Academy of Sciences-National Research Council, 1961

4 Worel B J, Deusen D V. Benefits of MnROAD Phase-II Research. Report 2015-19. Technical Report, Minnesota Department of Transportation Research Services \& Library, 2015. 20-21

5 Epps J A, Hand A, Seeds S, et al. Recommneded Performance-Related Specification for Hot-Mix Asphalt Construction: Results of the Westrack Project. Technical Report, National Academies Press, 2002

6 West R, Timm H D. Phase VI (2015-2018) NCAT Test Track Findings. Technical Report, National Center for Asphalt Technology, 2018

7 Timm D H, Newcomb D E. Perpetual pavement design for flexible pavements in the US. Int J Pavement Eng, 2006, 7: 111-119

8 Hornych P, Kerzreho J P, Chabot A, et al. The LCPC's ALT facility contribution to pavement cracking knowledge. In: Proceedings of the 6th International RILEM Conference on Cracking in Pavements. Abingdon: Taylor \& Francis Group, 2008. 13-23

9 Kerzrého J P, Hornych P, Chabot A, et al. Evaluation of the aggressiveness of different multi-axle loads using APT tests. In: Jones D, Harvey J, Imad L A Q, et al., eds. In: Proceedings of the 4th International Conference on Accelerated Pavement Testing. Boca Raton: CRC Press, 2012. 505-517

10 Metcalf J B. NCHRP Synthesis of Highway Practice 235. Application of Full-Scale Accelerated Pavement Testing. Technical Report, Transportation Research Board of the National Academy, Washington DC, 1996

11 Hugo F, Martin A L E. NCHRP Synthesis 325. Significatnt Findings from Full-Scale Accelerated Pavement Tetsting. Technical Report, Transportation Research Board of the National Academy, Washington DC, 2006

12 Wang X D. Design of pavement structure and material for full-scale test track (in Chinese). J High Transport Res Dev, 2017, 34: 30-37 [王旭东. 足 尺路面试验环道路面结构与材料设计. 公路交通科技, 2017, 34: 30-37]

13 Powell R B. A history of modern accelerated performance testing of pavement structures. In: Jones D, Harvey J, Imad L A Q, et al., eds. In: Proceedings of the 4th International Conference on Accelerated Pavement Testing. Boca Raton: CRC Press, 2012. 3-12

14 Steyn W J. Accelerated Pavement Testing-Based Pavement Design Catalogue. In: Jones D, Harvey J, Imad L A Q, et al., eds. In: Proceedings of the 4th International Conference on Accelerated Pavement Testing. Boca Raton: CRC Press, 2012. 519-526

15 Monismith C L, Brown S F. Developments in the Structural Design and Rehabilitation of Asphalt Pavements Over Three Quarters of A Century. In: Proceedings of Association of Asphalt Paving Technologists 1999 Annual Meeting, 1999. 232-246

16 Hudson W R, Monismith C L, Dougan C E. Use of PMS Data for Performance Monitoring with Superpave as an Example. Technical Report, Federal Highway Administration, 2002

17 Xie W Z, Yu S F. Fatigue life of asphalt pavement structure on semi-rigid base-circular test track study (in Chinese). China J High Transport, 1990, 3: 11-20 [谢文忠, 余叔藩. 半刚性基层沥青路面结构疲劳寿命的环道试验研究. 中国公路学报, 1990, 3: 11-20]

18 Zha X D, Zhang Q S. Laboratory study on the asphalt pavement structure (in Chinese). Chin Civ Eng J, 2000, 5: 92-96 [查旭东, 张起森. 沥青路面 结构室内直槽试验验证的研究. 土木工程学报, 2000, 5: 92-96]

19 Pan Y Q, Yang J. Survey of full-scale accelerated pavement test in China and abroad (in Chinese). J China Foreign High, 2005, 25: 137-140 [潘友 强, 杨军. 国内外足尺加速路面试验研究概况. 中外公路, 2005, 25: 137-140]

20 Huang X M, Zhang X B, Deng X J. Ashpalt pavement rutting prediction of high-grad highway (in Chinese). J Southest Univ (Nat Sci Ed), 2000, 30: 96-101 [黄晓明, 张晓冰, 邓学钧. 沥青路面车辙形成规律环道试验研究. 东南大学学报(自然科学版), 2000, 30: 96-101]

21 Meng S T. Research on the bituminous pavement per formance of semi-rigid base under the accelerated loading facility (ALF) (in Chinese). J High Transport Res Dev, 1997, 14: 59-64 [孟书涛. 半刚性基层沥青路面性能的加速加载试验研究. 公路交通科技, 1997, 14: 59-64]

22 Zhou G, Zhou J C, Hua B, et al. Study on perpetual deformat ion of asphalt pavement structures by circular track testing (in Chinese). J Tongji Univ (Nat Sci Ed), 2008, 36: 187-192 [周刚, 周进川, 华斌, 等. 沥青路面结构永久变形环道试验研究. 同济大学学报(自然科学报), 2008, 36: 187-192]

$23 \mathrm{Su} \mathrm{K}$, Wang C H, Zhou G. Rutting prediction model for asphalt concrete pavements based on accelerated pavement test (in Chinese). J Tongji Univ (Nat Sci Ed), 2008, 36: 493-497 [苏凯, 王春晖, 周刚, 等. 基于加速加载试验的沥青路面车辙预估研究. 同济大学学报(自然科学版), 2008, 36: 493-497]

24 Yan L, Zhou X Q, Li Y Z, et al. Reseach on heavy-load axle conversion for asphalt pavement based on rutting test on full scale linear track (in Chinese). J High Transport Res Dev, 2006, 23: 35-39 [颜利, 周晓青, 李宇峙, 等. 基于直道足尺车辙试验的沥青路面重载轴载换算方法研究. 公路交通科技, 2006, 23: 35-39] 
25 Zhou W H. Study on the development and selection optimization of an accelerated pavement testing facility for China (in Chinese). Doctor Dissertation. Xi'an: Chang'an University, 2011 [周文欢. 路面加速加载设施优选对策研究. 博士学位论文. 西安: 长安大学, 2011]

26 Chen S X, Zhang X N, Meng S T, et al. Fatigue damage in asphalt layer based on ALF accelerated loading test (in Chinese). J High Transport Res Dev, 2012, 29: 18-22 [陈少幸, 张肖宁, 孟书涛, 等. 基于ALF 加速加载试验的沥青层疲劳损伤. 公路交通科技, 2012, 29: 18-22]

27 Wang X D, Zhou X Y. Equivalent mechanical method of asphalt pavement structure based on material nonlinearity (in Chinese). China J High Transport, 2019, 32: 25-34 [王旭东, 周兴业. 基于材料非线性的沥青路面结构当量力学分析方法. 中国公路学报, 2019, 32: 25-34]

28 Zhou X Y. Structure response and non-linear analysis of asphalt pavement based on full-scale loop test (in Chinese). Doctor Dissertation. Harbin: Harbin Institute of Technology, 2019 [周兴业. 基于足尺环道试验的沥青路面结构响应及其非线性分析. 博士学位论文. 哈尔滨: 哈尔滨工业 大学, 2019] 


\title{
Research progress of long-life asphalt pavement behavior based on the RIOHTrack full-scale accelerated loading test
}

\author{
Lei Zhang, Xingye Zhou \& Xudong Wang ${ }^{*}$ \\ Research Institute of Highway, Ministry of Transport, Beijing 100088, China \\ * Corresponding author, E-mail: xd.wang@rioh.cn
}

Full-scale accelerated loading test is an efficient and effective method for simulating and studying long-term pavement performance because its loading and environment conditions are similar to those of real-world applications. In the past decades, this method has been recognized as an important support for the development of pavement design theory worldwide. In 2000, the long-life pavement was first presented by the researchers in Europe and the USA to obtain the most economical pavement during the whole life cycle. However, the completed design method of the long-life asphalt pavement has not been provided, especially for semi-rigid base asphalt pavement. In 2015, the Research Institute of Highway, Ministry of Transport constructed a 2.038-km-long full-scale field accelerated pavement testing track, which was named as RIOHTrack, to develop a long-life pavement suitable for China. The testing road has 25 asphalt pavement structure sections, and the average length of the testing section is $60 \mathrm{~m}$. In all of the testing sections there were 19 structural testing sections, which are classified into six types, namely, the thin asphalt layer semi-rigid base pavement, the normal semi-rigid base pavement used in China, the composite pavement, the inverted pavements, the thick asphalt layer asphalt pavement, and the full-depth asphalt pavement respectively. In the first research phase, RIOHTrack planned to complete 50 million equivalent single axle loads ESALs (10 tons standard axle loading) by using trucks under the real environment. During the accelerated loading, two types of pavement performance detections were conducted. The first type is the realtime strain/stress responses and the environment information captured by the monitor sensors, and the other type is the periodic pavement performance detection measured by auto-detecting devices or artificial measures. In this paper, the bearing capacity, service performances, and inner mechanism responses under the couple of loading and environment were analyzed on the basis of the whole detecting data captured from December 2016 to January 2020. Four main conclusions were drawn. First, the influence of loading and environment on performance is considerably, and the influence degree of environment is even larger than that caused by the loading. Second, the pavement performance has structural dependence, the ranking of the six main types varies if evaluated using different performance indices, and the rutting depth prediction accuracy depends on the structural type. Third, the stress/strain monitoring results verify the nonlinear characteristic of asphalt pavement structure under the temperature and loading. To calculate the nonlinear effect in pavement behavior, a new mechanical analysis method was presented, which considers material and geometric nonlinearity theory. Lastly, to improve the prediction accuracy of the rutting depth, we utilized multivariate statistics to build the new prediction model based on the measured rutting depth data, and this model considers the changes in loading number and temperature change. The stage research results illustrate that the different type of pavement structure has its advantages and disadvantages, so the type of the long-life asphalt pavement should be multiple choice. China has the longest mileages of semi-rigid base asphalt pavements. Hence, long-life, semi-rigid base asphalt pavement building, and maintenance technology should be developed. More works should be carried out on mechanism analysis, prediction models, and failure criteria, and the accelerated loading test, such as RIOHTrack, will mainly provide support.

pavement behavior, full-scale, accelerated loading test, Research Institute of Highway MOT Track (RIOHTrack), long-life asphalt pavement

doi: 10.1360/TB-2020-0287 